\title{
CONSUMER-BASED BRAND VALUE: A STUDY ON FOREIGN BANKS IN HO CHI MINH CITY MARKET
}

\author{
Doan Thi My Linh', Hoang Thi Phuong Thao ${ }^{2}$ \\ ${ }^{1.2}$ Ho Chi Minh City Open University
}

(Received: 17/06/2014; Revised: 10/07/2014; Accepted: 28/07/2014)

\begin{abstract}
The article presents an empirical study to discover consumers' perception on foreign banks' brand value which is said as one of key drivers for business success. The study is aimed at assisting brand managers to track their brand value and hence to improve their product and service quality. The conceptual model is founded on a consumer-based approach to brand value. To validate the model, a survey of 183 interviewees was carried out in four popular foreign banks in Ho Chi Minh City: Citibank, HSBC, ANZ and Standard Chartered (SCB). The collected data was tested and analyzed by Exploratory Factor Analysis. The study reveals that Brand Knowledge, Brand Differentiation, Brand Relevance and Brand Esteem correlate closely to each other and have a strong affect to Consumer-based Brand Value. The findings are discussed and the implications for banks' management are presented.
\end{abstract}

Keywords: Consumer-based brand value, foreign bank, brand management.

\section{Introduction}

In today competitive global market, to succeed, banks should put more and more focus on brand value. On average, brand value accounts for more than 50 percent of the market value of a company (Martensen and Gronholdt, 2010). Brand is a fundamental factor in business sustainability (Pinar et al., 2012). The question posed for brand managers is how to sustain brand value as well as develop a strong brand. To answer, it is essential to have an effective brand value measurement to periodically track and improve brand performance. Challenges for global bank brands include maintaining the consistency of a bank's brand and customer experience, remaining relevant to local consumers' specific needs and overcoming the image of "too big to pay attention to me" in the eyes of retail banking customers (Pinar et al., 2012, p. 360). The four leading foreign banks Citi, HSBC, ANZ and SCB have recently penetrated to Vietnam market which has specific localized cultural, environmental, political and customer behavioral features. In this circumstance, the measurement scale of brand value would be an ideal support for bank managements to figure out how to satisfy Vietnamese consumers as well as to position self against others.

In recent years, there have been extensive researches on customer-based brand equity/asset. Yet, a review of literature indicates that few empirical studies have addressed consumer-based brand value for foreign banks in Ho Chi Minh market. This paper focuses on evaluating the brand value of these foreign banks in Ho Chi Minh City to provide informative assistance supporting foreign banks' management.

\section{Related theory and analysis framework}

Consumer-based Brand Value is defined by many previous researches. Brand is the promise of a company delivered to its 
customers (Campell, 2002); is a group of associations in customer's mind enhancing cognitive value of a product or service (Keller, 2003); is all of tangible and intangible assets of a brand held in mind of the consumers (Gabay et al., 2009); is the influence of a brand in the marketing mix or the impact of the brand name on reactions to other features of the marketing mix, such as reactions to the actual product (Gabay et al., 2009); is the differential effect of brand knowledge on consumers response to the marketing of a brand (Keller, 1993); is intangible and exists more in the eyes and mind of the beholder than in the product or service itself (Gabay et al., 2009).

Proposed research framework and hypotheses: The proposed research framework is based on BAV (Brand Asset Valuator) model developed by Young and Rubicam (2003). Figure 1 shows the proposed research framework in which customer-based brand value is driven by four determinants: Brand Differentiation, Brand Relevance, Brand Esteem and Brand Knowledge.

\section{Figure 1. Research framework of Consumer-based Brand Value}

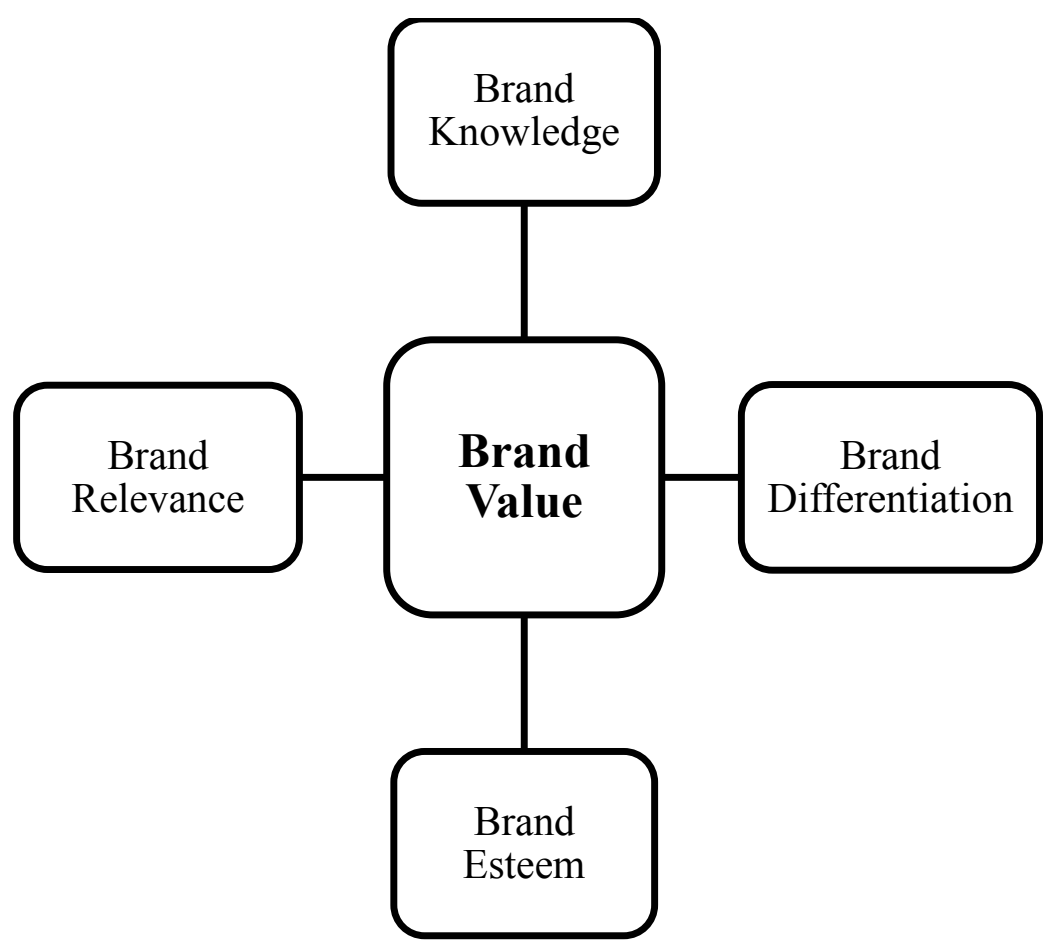

Brand Differentiation is said as the engine that pulls brand train. That is an ability of an offering to stand out from its competition which shows brand's prestige and its pricing power (Young and Rubicam, 2003). Brand differentiation is a measure of how distinct and unique the consumers perceive a particular brand to be.

Brand Relevance is the factor that drives penetration. If there is no connection between brand relevance to one' own life, the person will not engage in a serious relationship (Young and Rubicam, 2003). It can be considered as benefits that consumers obtain when using the brand. According to Keller (1993), this is personal value consumers attach to the product or service attributes that is they think how useful the product or service can bring them. Keller (1993) asserts that three major benefits are functional benefits (that are the more intrinsic advantages), experiential benefits (that relate to what it feels like to use the product or service) and symbolic benefits (that are the more extrinsic advantages of the brand). 
Brand Esteem represents for the extent to which consumers like a brand and holds it in high regard (Young and Rubicam, 2003). Esteem is a function of positive brand experience and brand communication and essentially the regard that the consumers hold for the brand (Babu et al., 2011).

Brand Knowledge is conceptualized as the associative network memory model consisting a set of nodes and links to the brand (Keller, 1993). Brand knowledge is not the facts about the brand: thoughts, feelings, perceptions, images, experiences, and so on that become linked to the brand in the minds of consumers (Keller, 2003).

The four factors not only affect positively to the Consumer-based Brand Value but also affect each other. Young and Rubicam (2000) discovers this kind of relationship by saying that all the four factors together build Brand Value and one factor is supported and strengthened by another. Differentiation measures the strength of the brand's meaning which attracts consumers' choice, brand essence and potential margin. Relevance measures the personal appropriateness of a brand to consumers and is strongly tied to household penetration. Relevance alone is not the key to brand success until it is attached with Differentiation. Brand Strength, an important indicator of future performance and brand health, is formed by Relevance and Differentiation. If a brand has established its Relevant Differentiation and won consumers' high Esteem, Brand Knowledge is the outcome and represents the successful culmination of building a brand. This combination is called Brand Stature.

The research framework is proposed as Brand Differentiation, Brand Relevance, Brand Esteem and Brand Knowledge are key components of Consumer-based Brand Value.

\section{Research methodology}

Qualitative research was carried out through a focus group. Ten customers were invited to a cordial discussion. The purpose of this meeting was to adjust, enhance and validate the observed variables and the suggested measurement scales. Participants were either those who were banking with the four banks more than six months or marketing managers of foreign banks, aged from 25 to 39 years old.

Basing on the feedback from the ten participants, the most popular foreign banks were agreed to be good to be selected as research objectives. They are Citi, HSBC, ANZ and Standard Chartered. Some movements between variables were made. Living up to its promise was designed to score Brand Differentiation in Martensen and Grønholdt study (2010). However, eighty percent of the focus group participants suggested using this variable to score Brand Esteem instead because the variable expressed the creditability and reliability of a brand. Furthermore, brand globalization was taken into account for such international brands. Especially, the very expensive cutting edge point to make a brand differentiated is the capability to position itself against others in a way that can localize its product and service features better. This would create brand value. Cateora and Graham (2011) also state that for global brands, culture differentiation dominates. Those brands who can localize better will win. Thus, Globalized but localized was added into the scale to measure this feature. Besides, Brand $X$ differs from other brands in a positive way, I am loyal to brand $X$, I like brand $X$ were eliminated as its meaning was too general and duplicated. Moreover, words and sentences were adjusted to provide better literacy. Thus, the result of qualitative research helps to build up the quantitative questionnaire.

Quantitative research was a survey on 190 customers across the four banks. The exploratory study was conducted in Ho Chi Minh City during April to June 2013. Each brand for which a respondent gave information was treated as a separate case. Interview was conducted during office hours at banks' transaction branches using predesigned questionnaires managed by googledoc installed in portable tablet. Sample was selected basing on quota sampling 
principle. This is non-probability method in which questionnaire is divided basing on the percentage of the number of customers from each bank against the total number of customers of the four banks. The planned versus actual sampling is presented in Table 1.

Table 1. Planned vs. actual sample

\begin{tabular}{cccccc}
\hline Bank & Population (*) & Percentage & $\begin{array}{c}\text { Planned sample } \\
\text { size }\end{array}$ & $\begin{array}{c}\text { Actual } \\
\text { sample size }\end{array}$ & $\begin{array}{c}\text { Planned } \\
\text { vs. actual }\end{array}$ \\
\hline HSBC & 19965 & $40 \%$ & 77 & 74 & $3.7 \%$ \\
\hline Citi & 14029 & $28 \%$ & 54 & 52 & $3.7 \%$ \\
\hline ANZ & 8094 & $16 \%$ & 31 & 30 & $3.7 \%$ \\
\hline SCB & 7284 & $15 \%$ & 28 & 27 & $3.7 \%$ \\
\hline Total & 49372 & $100 \%$ & 190 & 183 & \\
\hline
\end{tabular}

(*) Secondary data in December, 2012

After the returned surveys were reviewed and the invalid ones were eliminated, 183 valid answered questionnaires were coded to SPSS 18.0 for analysis purpose.

Brand Value from consumers' perspective is measured by 4 factors with 27 observed items, built on the reviewed measurement scales developed by Aaker (1996), Young and Rubicam (2003), Keller (2003), Nath and Bawa (2012), Cateora and Graham (2011), Martensen and Grønholdt (2010). These items are adjusted to be applicable with Vietnam market scenario. Four main factors are Brand Knowledge (4 variables), Brand Differentiation (5 variables), Brand Relevance (10 variables) and Brand Esteem (8 variables). The scale is designed as 5 point-scale Likert from 1-Totally disagree to 5-Totally agree.

Acceptable values are decided for different statistics based on review of literature (Hoang Trong and Chu Nguyen Mong Ngoc, 2008; Cooper and Schindler, 2003; Hair et al., 2006): minimum 0.7 for Cronbach Alpha; minimum 0.5 for factor loadings for itemcorrelation; $\mathrm{KMO}$ ranges from 0.5 to 1 ; and minimum $50 \%$ for cumulative sum of squared loadings. The maximum acceptable $p$ value for t-test and Bartlett's test was taken as 0.05 .

\section{Results and discussion}

\section{Descriptive statistics}

From 190 delivered questionnaires, 183 valid ones were encoded and analyzed. Nearly $55 \%$ of respondents are male, $45 \%$ is female. Typical age range is from 26 to 30 years old (49\%). Most of respondents are intellectual persons with education background from university graduate and above.

Statistics results describe 27 observed items. Different respondents bring different feedbacks on a same questionnaire. Average value of 27 observed items range slightly from 3.09 (is one of the best banks) to 3.79 (professional and competent staff). Observed variable is evaluated neither too much high nor too much low. Means are also different between different components in which Brand Relevance is the highest evaluated one (3.61) whereas Brand Differentiation (3.33) is the lowest. The result is shown in the Table 2 as below. 
Table 2. Descriptive statistics

\begin{tabular}{|c|c|c|c|c|}
\hline Observed Variables & Mean & Std deviation & Min & Max \\
\hline Recognizing name and logo correctly & 3.55 & 0.07 & 1 & 5 \\
\hline Understanding products and services & 3.33 & 0.06 & 1 & 5 \\
\hline Familiarizing brand & 3.48 & 0.06 & 1 & 5 \\
\hline Knowing about latest events & 3.37 & 0.07 & 1 & 5 \\
\hline Brand Knowledge & 3.43 & 0.73 & 2 & 5 \\
\hline Superior functional benefits & 3.25 & 0.06 & 1 & 5 \\
\hline Superior emotional benefits & 3.47 & 0.06 & 1 & 5 \\
\hline Unique selling point & 3.29 & 0.07 & 1 & 5 \\
\hline Innovative in products and services & 3.33 & 0.06 & 1 & 5 \\
\hline Globalized but localized & 3.31 & 0.06 & 1 & 5 \\
\hline Brand Differentiation & 3.33 & 0.68 & 1 & 5 \\
\hline Stable service quality & 3.68 & 0.05 & 2 & 5 \\
\hline Short transaction time & 3.47 & 0.06 & 2 & 5 \\
\hline Quick complaint handling & 3.54 & 0.06 & 1 & 5 \\
\hline Professional and competent staff & 3.67 & 0.05 & 1 & 5 \\
\hline Polite, courteous and forthcoming staff & 3.79 & 0.05 & 1 & 5 \\
\hline Correct transaction processing & 3.61 & 0.06 & 1 & 5 \\
\hline High technology & 3.64 & 0.06 & 2 & 5 \\
\hline User-friendly website, brochure, leaflets & 3.57 & 0.05 & 2 & 5 \\
\hline Suiting me as a person & 3.55 & 0.05 & 1 & 5 \\
\hline $\begin{array}{l}\text { Explaining clearly to customers about the } \\
\text { product features }\end{array}$ & 3.54 & 0.05 & 1 & 5 \\
\hline Brand Relevance & 3.61 & 0.54 & 2 & 5 \\
\hline Living up to its promise & 3.54 & 0.05 & 1 & 5 \\
\hline Positive brand association & 3.57 & 0.06 & 1 & 5 \\
\hline Feeling safe when banking & 3.74 & 0.06 & 2 & 5 \\
\hline Being proud to be bank's customer & 3.49 & 0.06 & 1 & 5 \\
\hline Being trustworthy and credible & 3.7 & 0.05 & 2 & 5 \\
\hline Growing in popularity & 3.56 & 0.06 & 1 & 5 \\
\hline Believe that other customers will love bank & 3.23 & 0.06 & 1 & 5 \\
\hline Willing to recommend & 3.44 & 0.06 & 1 & 5 \\
\hline Brand Esteem & 3.53 & 0.64 & 1 & 5 \\
\hline
\end{tabular}


Figure 2 shows the ranking of the four components of brand value, in which Brand Relevance gets the highest score and Brand Differentiation gets the lowest score. Service quality implicates in brand relevance during consumers are interacting with bank employees. When consumers think about a brand they will recall service quality of that brand. In other words, "brand is quality" and "quality is brand". The differentiation of service among foreign banks in Vietnam market is not large. Consumers do not recognize the dominance of any bank's brand. Styles and kinds of service are similar among these banks. The banks are easy to imitate to each other in providing services to customers. Brand Esteem is the second position after brand relevance in the ranking. It proves that after evaluating good quality of a brand they trust and be loyal to the brand.

Figure 2. Ranking of the components of Consumer-based Brand Value

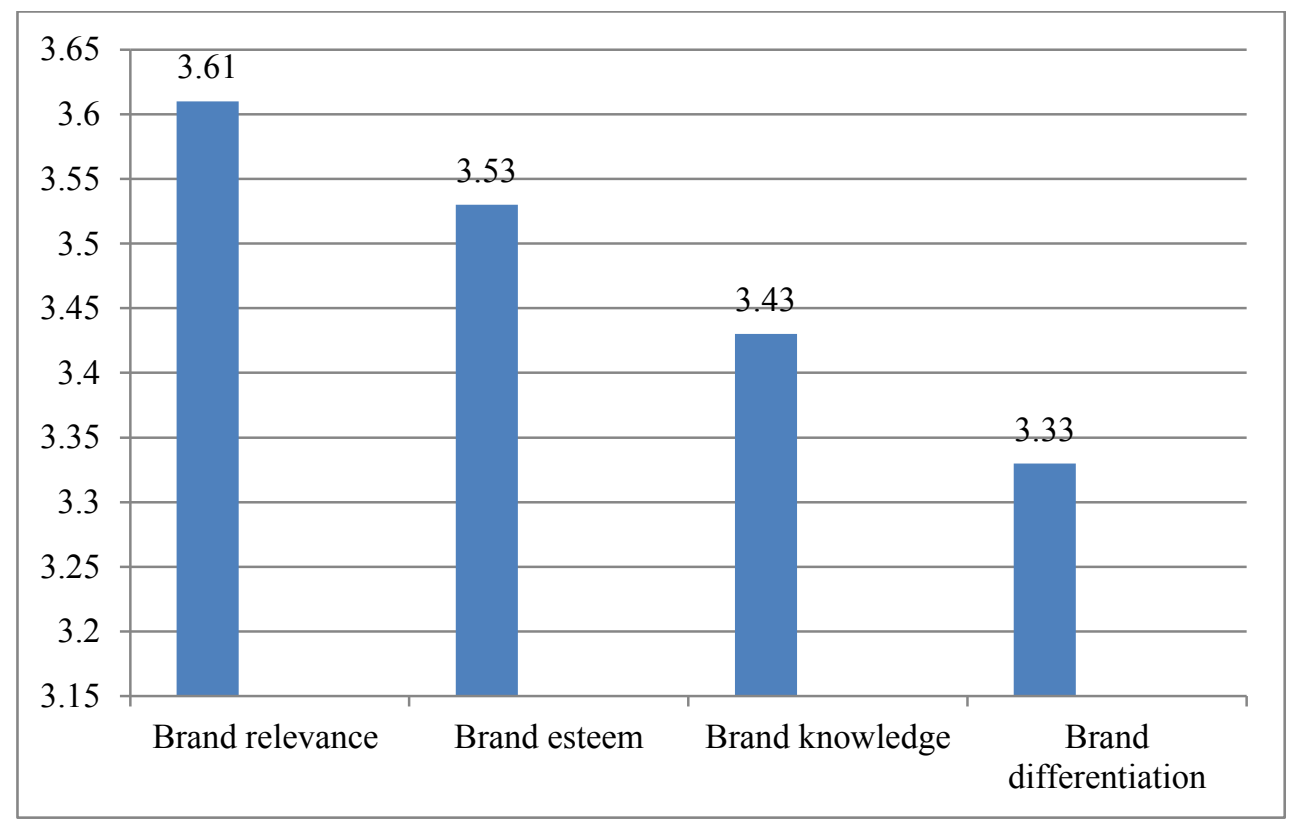

Cronbach's alpha and EFA analysis: The scale's reliability was tested via Cronbach alpha. Cronbach alphas of all variables are acceptable $(>0.7)$. Item-total correlations are good ( $>0.4)$. Item reliability was also assessed by examining the factor loadings of each item with its respective latent variables. KMO and Barlett's test is 0.918 for the four factors (sig. $=0.000<0.005$ ). All observed items are eligible to be continued with EFA analysis.

EFA analysis was conducted to examine whether the items produce proposed factors, and the results supports the proposed fourfactor solution. According to statistics result shown in Table 3, the all variables are grouped into four components at Eigenvalue 1.268 and cumulative $63.096 \%$. All factor loadings are higher than 0.05 . The four groups are named Brand Knowledge, Brand Differentiation, Brand Relevance and Brand Esteem. Hence, the measurement scale meets the satisfactory level of reliability and validity. 
Table 3. Rotated component matrix

\begin{tabular}{|c|c|c|c|c|c|}
\hline & Variables & \multicolumn{4}{|c|}{ Factor loadings } \\
\hline \multirow{4}{*}{ 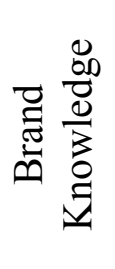 } & Recognizing name and logo correctly & & & & 0.740 \\
\hline & Understanding products and services & & & & 0.745 \\
\hline & Familiarizing brand & & & & 0.786 \\
\hline & Knowing about latest events & & & & 0.528 \\
\hline \multirow{5}{*}{ 己. } & Superior functional benefits & & \multicolumn{3}{|c|}{0.583} \\
\hline & Superior emotional benefits & & \multicolumn{3}{|c|}{0.642} \\
\hline & Unique selling point & & \multicolumn{3}{|c|}{0.729} \\
\hline & Innovative in products and services & & \multicolumn{3}{|c|}{0.671} \\
\hline & Globalized but localized & & \multicolumn{3}{|c|}{0.794} \\
\hline \multirow{10}{*}{ 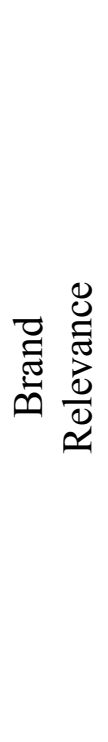 } & Stable service quality & \multicolumn{3}{|c|}{0.686} & \\
\hline & Short transaction time & \multicolumn{3}{|c|}{0.626} & \\
\hline & Quick complaint handling & \multicolumn{3}{|c|}{0.700} & \\
\hline & Professional and competent staff & \multicolumn{3}{|c|}{0.698} & \\
\hline & Polite, courteous and forthcoming staff & \multicolumn{3}{|c|}{0.724} & \\
\hline & Correct transaction processing & \multicolumn{3}{|c|}{0.718} & \\
\hline & High technology & \multicolumn{3}{|c|}{0.646} & \\
\hline & User-friendly website, brochure, leaflets & \multicolumn{3}{|c|}{0.565} & \\
\hline & Suiting me as a person & \multicolumn{3}{|c|}{0.626} & \\
\hline & $\begin{array}{l}\text { Explaining clearly to customers about the } \\
\text { product features }\end{array}$ & \multicolumn{3}{|c|}{0.618} & \\
\hline \multirow{8}{*}{ 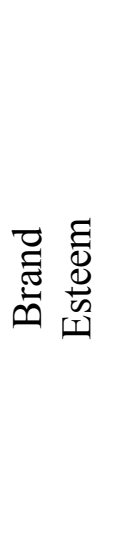 } & Living up to its promise & 0.673 & & & \\
\hline & Positive brand association & 0.683 & & & \\
\hline & Feeling safe when banking & 0.656 & & & \\
\hline & Being proud to be a bank's customer & 0.669 & & & \\
\hline & Being trustworthy and credible & 0.718 & & & \\
\hline & Growing in popularity & 0.712 & & & \\
\hline & Other customers will love bank & 0.760 & & & \\
\hline & Willing to recommend to others & 0.639 & & & \\
\hline
\end{tabular}

The correlation between the four factors was examined. Table 4 shows that there is a significant relationship between them. Each of the four factors has a strong correlation with the other three ones. The correlation between Brand Knowledge and Brand Differentiation, Brand Differentiation and Brand Relevance, Brand Relevance and Brand Esteem, Brand 
Esteem and Brand Knowledge, Brand respectively. It is divulged that Brand Knowledge and Brand Relevance, Brand Differentiation and Brand Esteem have a Differentiation and Brand Esteem are 0.613, closest relationship.

$0.459, \quad 0.623,0.608, \quad 0.470$ and 0.709

Table 4. Correlation matrix

\begin{tabular}{llcccc}
\hline & & BK & BD & BR & BE \\
\hline \multirow{4}{*}{$\begin{array}{c}\text { Pearson } \\
\text { Correlations }\end{array}$} & Brand Knowledge (BK) & 1 & $0.613^{* *}$ & $0.470^{* *}$ & $0.608^{* *}$ \\
\cline { 2 - 6 } & Brand Differentiation (BD) & & 1 & $0.459^{* *}$ & $0.709^{* *}$ \\
\cline { 2 - 6 } & Brand Relevance (BR) & & & 1 & $0.623^{* *}$ \\
\cline { 2 - 6 } & Brand Esteem (BE) & & & 1 \\
\hline
\end{tabular}

Note: **Significance at $p<0.01$

One-way ANOVA Test: In order to test the difference in perceived brand value between the four banks in terms of Income, Time of Banking and Brand of Bank, an
ANOVA test is performed. The result in Table 5 shows that those criteria are perceived differently (sig. $<0.05$ ).

Table 5. One-way Anova result

\begin{tabular}{|c|c|c|c|c|c|c|c|c|}
\hline & \multirow[b]{2}{*}{ Group difference } & \multirow[b]{2}{*}{$\mathbf{N}$} & \multirow[b]{2}{*}{ Mean } & \multirow[b]{2}{*}{$\begin{array}{l}\text { Std. } \\
\text { dev. }\end{array}$} & \multicolumn{4}{|c|}{ Post Hoc tests } \\
\hline & & & & & Group A & Group B & $\begin{array}{c}\text { Mean } \\
\text { difference } \\
(\mathrm{A}-\mathrm{B})\end{array}$ & Sig. \\
\hline & \multicolumn{8}{|c|}{ Income } \\
\hline \multirow{3}{*}{ 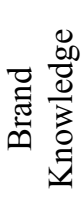 } & Less than 10MM (*) & 63 & 3.20 & 0.71 & Less than 10MM & From $11 \mathrm{MM}$ to $20 \mathrm{MM}$ & -0.40 & 0.00 \\
\hline & From $11 \mathrm{MM}$ to $20 \mathrm{MM}$ & 72 & 3.60 & 0.78 & From $11 \mathrm{MM}$ to $20 \mathrm{MM}$ & More than $21 \mathrm{MM}$ & 0.12 & 0.63 \\
\hline & More than $21 \mathrm{MM}$ & 48 & 3.48 & 0.61 & More than $21 \mathrm{MM}$ & Less than $10 \mathrm{MM}$ & 0.28 & 0.10 \\
\hline \multirow{3}{*}{ 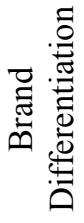 } & Less than 10MM & 63 & 3.24 & 0.57 & Less than $10 \mathrm{MM}$ & From $11 \mathrm{MM}$ to $20 \mathrm{MM}$ & -0.19 & 0.22 \\
\hline & From $11 \mathrm{MM}$ to $20 \mathrm{MM}$ & 72 & 3.44 & 0.62 & From $11 \mathrm{MM}$ to $20 \mathrm{MM}$ & More than 21MM & 0.16 & 0.42 \\
\hline & More than 21MM & 48 & 3.28 & 0.87 & More than $21 \mathrm{MM}$ & Less than 10MM & 0.03 & 0.96 \\
\hline \multirow{3}{*}{ 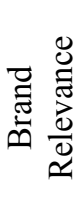 } & Less than $10 \mathrm{MM}$ & 63 & 3.46 & 0.54 & Less than $10 \mathrm{MM}$ & From $11 \mathrm{MM}$ to $20 \mathrm{MM}$ & -0.15 & 0.21 \\
\hline & From $11 \mathrm{MM}$ to $20 \mathrm{MM}$ & 72 & 3.61 & 0.55 & From $11 \mathrm{MM}$ to $20 \mathrm{MM}$ & More than $21 \mathrm{MM}$ & -0.19 & 0.14 \\
\hline & More than $21 \mathrm{MM}$ & 48 & 3.80 & 0.45 & More than $21 \mathrm{MM}$ & Less than 10MM & 0.34 & 0.00 \\
\hline \multirow{3}{*}{ 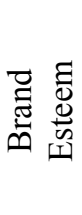 } & Less than 10MM & 63 & 3.45 & 0.56 & Less than $10 \mathrm{MM}$ & From $11 \mathrm{MM}$ to $20 \mathrm{MM}$ & -0.12 & 0.50 \\
\hline & From $11 \mathrm{MM}$ to $20 \mathrm{MM}$ & 72 & 3.58 & 0.70 & From $11 \mathrm{MM}$ to $20 \mathrm{MM}$ & More than $21 \mathrm{MM}$ & 0.00 & 1.00 \\
\hline & More than $21 \mathrm{MM}$ & 48 & 3.58 & 0.63 & More than $21 \mathrm{MM}$ & Less than 10MM & 0.13 & 0.56 \\
\hline
\end{tabular}




\section{Time of Banking}

\begin{tabular}{|c|c|c|c|c|c|c|c|}
\hline \multirow{3}{*}{ 可 } & From 6 mths to 1 year & 60 & 3.39 & $0.70 \begin{array}{l}\text { From } 6 \text { months to } 1 \\
\text { year }\end{array}$ & From 1 year to 3 years & -0.05 & 0.93 \\
\hline & From 1 year to 3 years & 87 & 3.44 & 0.73 From 1 year to 3 years & More than 3 years & -0.04 & 0.95 \\
\hline & More than 3 years & 36 & 3.48 & 0.79 More than 3 years & From $6 \mathrm{mths}$ to 1 year & 0.09 & 0.84 \\
\hline \multirow{3}{*}{ 离 } & From 6 mths to 1 year & 60 & 3.32 & $\begin{array}{l}\text { From } 6 \text { months to } 1 \\
\text { year }\end{array}$ & From 1 year to 3 years & -0.06 & 0.87 \\
\hline & From 1 year to 3 years & 87 & 3.37 & 0.62 From 1 year to 3 years & More than 3 years & 0.13 & 0.60 \\
\hline & More than 3 years & 36 & 3.24 & 0.89 More than 3 years & From 6 mths to 1 year & -0.07 & 0.87 \\
\hline \multirow{3}{*}{ 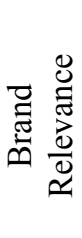 } & From 6 mths to 1 year & 60 & 3.60 & $0.45 \begin{array}{l}\text { From } 6 \text { months to } 1 \\
\text { year }\end{array}$ & From 1 year to 3 years & 0.07 & 0.71 \\
\hline & From 1 year to 3 years & 87 & 3.53 & 0.57 From 1 year to 3 years & More than 3 years & -0.25 & 0.05 \\
\hline & More than 3 years & 36 & 3.78 & 0.55 More than 3 years & From 6 mths to 1 year & 0.18 & 0.25 \\
\hline \multirow{4}{*}{ 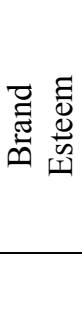 } & From 6 mths to 1 year & 60 & 3.58 & $\begin{array}{l}0.59 \begin{array}{l}\text { From } 6 \text { months to } 1 \\
\text { year }\end{array} \\
\end{array}$ & From 1 year to 3 years & 0.09 & 0.66 \\
\hline & From 1 year to 3 years & 87 & 3.49 & 0.68 From 1 year to 3 years & More than 3 years & -0.08 & 0.81 \\
\hline & More than 3 years & 36 & 3.57 & 0.62 More than 3 years & From 6 mths to 1 year & -0.02 & 0.99 \\
\hline & \multicolumn{7}{|c|}{ Brand of Bank } \\
\hline \multirow{6}{*}{ 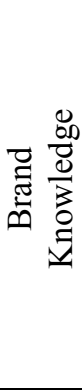 } & Citi & 52 & 3.86 & 0.63 Citi & HSBC & 0.47 & 0.00 \\
\hline & HSBC & 74 & 3.39 & $0.63 \mathrm{HSBC}$ & ANZ & 0.17 & 0.65 \\
\hline & ANZ & 30 & 3.22 & 0.77 ANZ & $\mathrm{SCB}$ & 0.24 & 0.52 \\
\hline & $\mathrm{SCB}$ & 27 & 2.97 & $0.74 \mathrm{SCB}$ & Citi & -0.88 & 0.00 \\
\hline & & & & Citi & ANZ & 0.64 & 0.00 \\
\hline & & & & SCB & HSBC & -0.41 & 0.03 \\
\hline \multirow{6}{*}{ 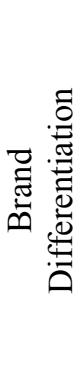 } & Citi & 52 & 3.58 & 0.63 Citi & HSBC & 0.13 & 0.67 \\
\hline & HSBC & 74 & 3.65 & $0.46 \mathrm{HSBC}$ & ANZ & 0.22 & 0.33 \\
\hline & ANZ & 30 & 3.23 & $0.69 \mathrm{ANZ}$ & SCB & 0.59 & 0.00 \\
\hline & SCB & 27 & 2.64 & $0.80 \mathrm{SCB}$ & Citi & -0.94 & 0.00 \\
\hline & & & & Citi & ANZ & 0.35 & 0.06 \\
\hline & & & & SCB & HSBC & -0.81 & 0.00 \\
\hline \multirow{6}{*}{ 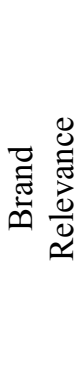 } & Citi & 52 & 3.79 & 0.49 Citi & HSBC & 0.11 & 0.62 \\
\hline & HSBC & 74 & 3.68 & $0.40 \mathrm{HSBC}$ & ANZ & 0.23 & 0.15 \\
\hline & ANZ & 30 & 3.44 & $0.53 \mathrm{ANZ}$ & $\mathrm{SCB}$ & 0.21 & 0.42 \\
\hline & $\mathrm{SCB}$ & 27 & 3.24 & $0.74 \mathrm{SCB}$ & Citi & -0.55 & 0.00 \\
\hline & & & & Citi & ANZ & 0.35 & 0.02 \\
\hline & & & & SCB & HSBC & -0.44 & 0.00 \\
\hline
\end{tabular}




\begin{tabular}{|c|c|c|c|c|c|c|}
\hline \multirow{6}{*}{ 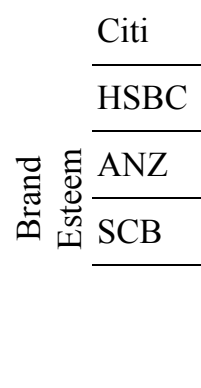 } & 52 & 3.88 & 0.58 Citi & HSBC & 0.32 & 0.01 \\
\hline & 74 & 3.56 & $0.53 \mathrm{HSBC}$ & ANZ & 0.22 & 0.29 \\
\hline & 30 & 3.34 & $0.58 \mathrm{ANZ}$ & SCB & 0.34 & 0.11 \\
\hline & 27 & 3.00 & $0.67 \mathrm{SCB}$ & Citi & -0.88 & 0.00 \\
\hline & & & Citi & ANZ & 0.54 & 0.00 \\
\hline & & & SCB & HSBC & -0.56 & 0.00 \\
\hline
\end{tabular}

(*) $M M=$ million Vietnam Dong

First of all, from income perspective, the ANOVA table shows that there is only statistical difference in Brand Knowledge and Brand Relevance (sigs < 0.05). Brand Knowledge is perceived differently only between the 2 groups of customers who have low and average income (less than 10 and from 11 to 20 million). The result interprets that low income consumers have a limitation to know more about foreign banks information. The highest knowledge value is from group of consumers who have income from 11 to 20 million (3.60). This once again emphasizes the communication between foreign banks to their targeted consumers is somehow effective. Brand Relevance is proved to be parallel with consumers' income. Higher income brings higher brand relevance. It is explainable that the high income consumers find it more relevant to bank with foreign banks with premier services and products.

In addition, Brand Relevance is different between those who have different banking time period with foreign banks (sig. $<0.05$ ). Mean of group of old-to-bank consumers ( $>3$ years of banking) is higher than that of new-tobank one (from 6 months to 1 year of banking). The more time spent with foreign banks, the more relevance consumers perceive. Thus, brand value is differentiated by Time of Banking.

Last but not least, the study reveals that each factor (Brand Knowledge, Brand Differentiation, Brand Relevance and Brand Esteem) from each of the four banks is assessed remarkably unequal. Brand value of each bank is perceived with various levels of dissimilarity. HSBC ranks the best in brand differentiation (mean $=3.65$ ). By the advantage of the first footer, HSBC likely penetrates deeper into Ho Chi Minh market to understand consumers' functional and emotional distinct benefits to tailor consumers' needs and achieve such a high brand differentiation. Citi emerges as the most esteemed brand (mean $=3.88$ ). SCB brand value is considered the lowest one while ANZ is neither too high nor too low (Table 5).

Overall, the findings indicate substantial support for the proposed model.

\section{Conclusion and managerial implication}

\section{Conclusion}

The research result discloses that the four factors have a close correlation to each other. Differentiation emerges as a driver to brand value. Differentiation closely correlates to Esteem. The deeper Differentiation the brand is perceived, the higher Esteem consumers hold for the bank and vice versa. This unveils many direct and helpful messages to brand managers: to strengthen the brand value, the four pillars (Differentiation, Knowledge, Relevance and Esteem) need to be tracked, developed and sustained properly.

Although the response of consumers to brand values of the four foreign banks is at different levels, the overall feedback is positive (mean $>2.5$ ). It is explainable as nowadays the advances in banking technology have facilitated foreign banks to easily provide its consumers with convenient and premier services.

The difference in perceived brand value between the four banks is illustrated. Citi 
outnumbers others in terms of Esteem and Knowledge. This is evidenced by mean 3.88 and 3.86 respectively (Table 5). Whereas, HSBC is the most relevant brand in comparison to other three banks (mean 3.68) which would have been useful for HSBC's brand manager to recognize their strength to sustain and other banks to learn how to better their Brand Relevance as well. Overall, Citi and HSBC are ranked highest while ANZ and SCB need to be improved.

In conclusion, it appears that there is no clear pattern indicating how strength a brand is. The above result can be considered as a reference to weight one brand against others in a specific way. This measurement scale can be referred as a tool for brand managers to periodically track their own brand performance via consumers' perception.

\section{Implication}

Gabay (2009) declares that while products are made in the factory, brand is in the consumers' mind. This study also emphasizes that consumers' brand esteem plays the most important role in determining value of a brand. A good manner of keeping promise creates a positive image in customer's mind. It is recommended to set up a welltrained front-liner staffs who deliver state of the art service and excellent turnaround time to customers. Customers should not be told more than we can deliver.

With the fact that the higher regard and awareness consumers hold for a brand, the better brand value is; strategic branding requires a meaningful differentiation. In the competitive market place, differentiation is a weapon. Banks need to equip self with this weapon in which unique selling points are the bullets. Bullets shall be designed the way it cannot be imitated by other competitors.

The consumers are keeping looking for a real value added brand. Additional practical implication suggests that product should be designed based on consumers' needs as brand relevance is one of key drivers for a high brand value. Benefits are always attractive to customer. When branding, banks need to focus on both functional benefits such as interest rate, financial support, etc. and emotional benefits such as security, satisfaction, etc. Consumers' need should be used to shape a brand.

Fierce competition between brands brings lots of threats to banks. Information technology development provides so many options to consumers. As consumers are now more educated than ever, there will be soon no room for brands which fail to keep its promise. As the result, the consumers are more likely to look elsewhere. This definitely leads to brand erosion.

\section{Limitations and Direction for Future Research}

First off, it is noteworthy that the measurement used in this study does not transfer the brand value to dollar value. Due to time and resource limitation, comparison between brand value and financial performance was not carried out.

On second thoughts, the survey was conducted in foreign banks only while it can be used for different types of banks such as government-owned banks or local private banks. Among the limitations, the sample is limited to convenience sample of the four most popular foreign banks $(n=183)$ within Ho Chi Minh City. If the sample size was bigger and the geographic is wider, the research result would be more reliable. We recommend a future study cover more cities and more types of bank with bigger sample size. Also, future study can perform the comparison for brand value between different types of bank to identify the competitive edge of each. 


\section{REFERENCES}

Campell, M. (2002). "Building Brand Equity”. International Journal of Medical Marketing, Vol. 2, No. 3, Henry Stewart Publications.

Cateora, P. \& Graham, J. (2011). International Marketing. McGraw-Hill/Irwin, International Edition, 15th Edition.

Gabay, G.; Moskowitz, H.; Beckley, J. (2009). "Consumer centered brand value of foods: drivers and segmentation". Journal of Product and Brand Management, Vol. 18, No. 1, p.4-16, Emerald Group Publishing Limited.

Keller, K. L. (1993). "Conceptualizing, Measuring, and Managing Customer-based Brand Equity". Journal of Marketing, Vol. 57, No. 1, American Marketing Association.

Keller, K. L. (2003). Measuring Brand Equity. Dartmouth College.

Martensen, A. and Grønholdt, L. (2010). "Measuring and managing brand equity". International Journal of Quality and Service Sciences, Vol. 2, No. 3, p. 300-316, Emerald Group Publishing, Limited.

Nath, P. and Bawa, A. (2012). "Measurement of Brand Equity of Services - Scale Construction and Validation". Journal of Services Research, Vol.11, No. 2, Institute for International Management and Technology.

Pinar, M.; Girard T.; Eser Z. (2012). "Consumer-based brand equity in banking industry: A comparison of local and global banks in Turkey". International Journal of Bank Marketing, Vol. 30, No. 5, p. 359-375, Emerald Group Publishing Limited.

Prasad, K. and Dev, C.S. (2000). "Managing hotel brand equity: a customer-centric framework for assessing performance". Cornell Hotel and Restaurant Administration Quarterly, Vol. 41 No. 3, pp. 22-31.

Young and Rubicam (2000). Brand Asset Valuator. Young and Rubicam Inc.

Young and Rubicam (2003). BAV Blue Book. Young and Rubicam Inc. 